\title{
ОСОБЛИВОСТІ АДАПТАЦІЇ СТУДЕНТІВ ПЕРШОГО КУРСУ В УМОВАХ ЗМІШАНОЇ ФОРМИ НАВЧАННЯ В ПЕРІОД КАРАНТИННИХ ОБМЕЖЕНЬ
}

\author{
O. Z. Ivanchenko, O. Z. Melnikova, G. R. Mikaelyan \\ Zaporizhzhya State Medical University \\ PECULIARITIES OF FIRST-YEAR STUDENTS’ ADAPTATION \\ IN THE CONDITIONS OF THE MIXED FORM OF EDUCATION \\ IN THE PERIOD OF QUARANTINE LIMITATIONS
}

\begin{abstract}
Анотація. Представлена робота містить результати дослідження актуальної педагогічної проблеми сьогодення, яка полягає в суттєвих змінах умов, у яких здійснюється адаптація до навчання студентів-першокурсників у закладах вищої освіти (3ВО). В умовах карантинних обмежень відбувався перехід на змішану його форму, коли заняття проводяться дистанційно за тим самим розкладом, який був створений на початку року для аудиторної роботи, з повною візуалізацією навчального процесу. Метою дослідження було виявлення особливостей перебігу адаптації студентів першого курсу медичного факультету та визначення організаційних засобів, які могли б сприяти більш успішній адаптації першокурсників. В добровільному анкетуванні взяли участь 64 студенти медичного факультету віком від 17 до 20 років. Питання анкети були сформульовані авторами статті самостійно на основі наукової літератури, присвяченої проблемам адаптації студентів. Показано, що більш ніж 80 \% студентів були дуже зацікавлені майбутньою професією, і тільки 65,1% опитаних оцінили відношення до неї як «дуже подобається» після нетривалого навчання. Рівень задоволеності результатами навчання у студентів виявився невисоким - лише 30 \% 3 них були повністю задоволеними. Серед причин, які впливають на результати навчання і заважають адаптації, 52,4 \% опитаних першокурсників назвали напругу і втому від занять, 60 \% - опанування нових його форм, а 26 \% студентів - пристосування до вимог викладачів. Виявилось, що соціально-біологічні аспекти адаптації в умовах дистанційного навчання мали полегшені прояви - тільки $15 \%$ першокурсників відмітили труднощі раціонального планування свого часу, тоді як 73,3 \% опитаних молодих людей проблем із цим не мали, залишаючись вдома із батьками. При визначенні стану психологічної адаптації виявилось, що майже кожен другий з опитаних першокурсників відчував підвищену тривожність, внутрішню напругу, невпевненість у своїх силах, мав порушення сну. Студенти відзначили, що організація змішаної форми навчання з повною його візуалізацією їх дисциплінує, мотивує на найкращу роботу і відповідальне ставлення, проте тільки 43,2 \% учасників анкетування визнали, що вони беруть активну участь у спілкуванні он-лайн, тоді як інші - на вимогу викладачів. Враховуючи вищевикладене, можна зробити висновок, що при змішаній формі навчання дидактичні, психологічні і професійні складові загальної адаптації студентів потребують особливої уваги з боку організаторів навчального процесу.
\end{abstract}

Ключові слова: адаптація; медичний факультет; першокурсники; змішана форма навчання.

Abstract. The presented work contains the results of a study of the current today pedagogical problem, which consists in significant changes in the conditions in which the adaptation of first-year students to the study in higher education institutions (HEI) take place. Under the conditions of quarantine restrictions, there was a transition to its mixed form, when classes are held remotely according to the same schedule, which was created at the beginning of the year for classroom work, with full visualization of the educational process. The aim of the study was to identify the peculiarities of the first-year medical students' adaptation course and to identify organizational tools that could contribute to a more successful adaptation of freshmen. In the voluntary survey64 medical students aged 17 to 20 took part. The questions of the questionnaire were formulated by the authors of the article independently based on scientific literature devoted to the problems of students' adaptation. It is shown, that more than $80 \%$ of students were very interested in the future profession, and only $65.1 \%$ of respondents rated the attitude to it as "very like" after a short study. The level of satisfaction with the results of students' studies was not high - only $30 \%$ of respondents were completely satisfied. Among the reasons that affect learning outcomes and hinder adaptation $52.4 \%$ of surveyed freshmen named stress and fatigue from classes, $60 \%$ - mastering its new forms, and $26 \%$ of students - adaptation to the requirements of teachers. It turned out that the socio-biological aspects of adaptation in distance learning

(c) О. 3. Іванченко, О. 3. Мельнікова, Г. Р. Мікаєлян 
were mild - only $15 \%$ of freshmen noted the difficulties of rational planning of their time, while $73.3 \%$ of young people surveyed had no problems with it, staying at home with their parents. Students noted that the organization of a mixed form of education with its full visualization disciplines them, motivates them for the best work and responsible attitude, but only $43.2 \%$ of respondents admitted that they are actively involved in online communication, while others - at the request of teachers. Given the above, we can conclude that in a mixed form of education didactic, psychological and professional components of the general adaptation of students require special attention from the organizers of the educational process.

Key words: adaptation; medical faculty; first-year students; mixed form of education.

Вступ. Одним із найважливіших завдань закладів вищої освіти (3ВО) є створення умов для успішної адаптації та соціалізації першокурсників. Над вирішенням цього питання повинні працювати всі учасники навчального процесу. Відомо, що адаптація першокурсників є багатогранною проблемою, яка обумовлена для кожного з них змінами соціальної ролі і кола спілкування, потребою самоствердитися у новому колективі, прийняти і виконувати вимоги університету, пристосуватися до самостійного проживання без батьків. Все це складає зміст соціальної складової загальної адаптації студентів. Мають реалізуватися й інші її аспекти: сформуватися вміння здійснювати саморегуляцію поведінки і своєї діяльності, відчувати стан психологічного комфорту (психологічна адаптація), якісно змінити режими сну, харчування, фізичних і нервових навантажень (біологічна адаптація). Крім того, вступ до ЗВО вимагає від студента пристосування до нової системи навчання, до таких форм проведення занять, які відрізняються від шкільних (дидактична адаптація).

Особливо важливим аспектом загальної адаптації студентів медичних університетів $є$ професійна адаптація. Добре відомим $є$ той факт, що для успішного навчання потрібна позитивна професійна мотивація. Показано, що у більшості студентів медичного факультету вона є досить високою вже на першому курсі, що може бути зумовлено специфікою самої професії лікаря, вибір якої, як правило, є досить усвідомленим молодими людьми. Він $є$ однією з перших умов якісного навчання, а в подальшому й успішного професійного життя, i формування любові, інтересу до обраної професії потребує уваги протягом всього періоду освіти в університеті.

Усі вказані аспекти загальної адаптації тісно пов’язані між собою, і для того, щоб вона відбулася швидко і якісно, з найменшими негативними впливами на організм молодої людини, необхідно, щоб різні складові даного процесу були реалізовані і доповнювали одна одну.

На сьогодні проблема адаптації набула ще однієї грані. Пандемія коронавірусного захворювання призвела до введення обмежень на групові зібрання, освітні заходи, що змусило ЗВО в найкоротші терміни перевести навчальні програми на онлайнплатформи $[8,9,11,13]$. Потрібно відмітити, що сьогоднішні першокурсники вже мають досвід онлайн-навчання в школі: вони добре вміють користуватися програмним забезпеченням, бачать його позитивні і негативні сторони, в цілому відносяться до нього з розумінням. Водночас питання адаптації саме до навчання в 3 ВО залишились актуальними, і вона дещо обтяжилась ізоляцією, великою кількістю роботи, яку треба виконати самостійно тощо.

Проблема адаптації студентів-першокурсників саме медичних спеціальностей є загальносвітовою, про що свідчить велика кількість публікацій з цього питання і в Україні [1-3, 12], і в інших країнах [5, 7, 10, 15]. «Успішна адаптація студентів першого курсу на сьогодні залишається невирішеною проблемою, незважаючи на досить значний об' $є$ м інформації щодо проблеми, загальновизнаною $€$ думка що дане питання потребує уточнення і подальшого вивчення» [3], особливо в сучасних умовах існування всього світу.

Враховуючи той факт, що ступінь пристосування студентів, які тільки починають своє професійне навчання, в подальшому відіграє вагому роль у розкритті і реалізації їх можливостей у майбутній професії, впливає на якість життя молодих людей, а також є обов'язковою умовою їх психологічного благополуччя, було сформульовано мету представленої роботи.

Мета дослідження - виявлення основних проблем студентів першого курсу медичного факультету в умовах змішаної форми навчання в період карантинних обмежень; з'ясування, до яких умов вже вдалося пристосуватися; визначення засобів допомоги й організація заходів, що сприяли би більш успішній адаптації першокурсників.

Методи дослідження. В добровільному анкетуванні брали участь 64 студенти медичного факультету віком від 17 до 20 років. Питання анкети були сформульовані авторами статті за допомогою дослідженої науково-методичної літератури, в якій вивчаються проблеми адаптації студентів першого 
курсу, а саме методика виявлення типових труднощів першокурсників Б. Г. Мещерякова; «Адаптація студентів до коледжу» Baker, Siryk [7].

Результати дослідження. Визначення критеріїв адаптації є складним теоретичним і практичним питанням наукових досліджень. У роботі [5] показано, що позитивна професійна та навчальна мотивація значно спрощує і прискорює процеси адаптації загалом. Серед 64 опитаних студентів основними причинами вступу до медичного університету назвали бажання стати висококваліфікованими спеціалістами (82,5 \%) і зацікавленість майбутньою професією (80,9%). Серед інших причин вибору університету були позитивні зовнішні мотиви, а саме: отримання диплома про вищу медичну освіту, бажання і порада батьків та інші. Вважають, що якщо такі мотиви не є пріоритетними, то вони не заважають успішній адаптації, i, навіть навпаки, можуть їі прискорювати.

Відношення до обраної спеціальності після нетривалого навчання студенти оцінили так: «дуже подобається» - 65,1 \% і «мабуть, подобається» 28,6 \% анкетованих. Крім того, були студенти (6 \%), яким ще важко відповісти на таке запитання. Отримані в результаті анкетування дані свідчать, що студентам вже потрібна допомога в професійній мотивації. На першому курсі в навчальному графіку переважають фундаментальні дисципліни, які готують до усвідомленого, зрілого, якісного сприйняття клінічних дисциплін. У деяких першокурсників може з’явитися враження, що навчання в університеті на лікаря не зовсім те, що вони очікували. Викладачам потрібно більше уваги приділяти актуальності вивчення тієї чи іншої дисципліни. Студент завжди повинен знати, де отримані знання йому знадобяться в його наступному навчанні і майбутній професійній діяльності.

Успішність й ефективність адаптації студентів залежать від усвідомлення активної ролі самої особистості в процесах пристосування до нових умов життя, а визначальним внутрішнім критерієм адаптації першокурсника в умовах закладу вищої освіти є стан його задоволення процесом і результатами навчання. Опитування проводилося після першої проміжної навчальної атестації. Тому ми вирішили дізнатися у першокурсників про рівень задоволеності результатами свого навчання. Переважна більшість студентів 1 курсу навчається «добре» - 81 \%, а «відмінно» і «задовільно» - по 9 \% опитаних. При цьому лише 30 \% всіх першокурсників були задоволеними результатами свого навчання, 65 \% хотіли би покращити свої результати. Зовсім не задоволеними залишилися близько 5 \% опитаних студентів.

Як було сказано раніше, загальна адаптація до навчання $є$ багатогранним процесом, в якому всі складові пов’язані між собою і впливають одна на одну. Дидактична адаптація до нових форм навчання (лекції, практичні заняття, семінари), вміння працювати самостійно, а саме необхідність ознайомитися з навчальними матеріалами, проаналізувати їх зміст, зробити висновки і чітко сформулювати свої думки, неможлива без психологічної, біологічної, соціальної адаптації. У свою чергу, успішне пристосування до нових умов навчання позитивно позначається на психологічному стані, фізичному здоров’ї, соціальних відносинах.

Серед причин, які впливають на результати навчання і заважають адаптації, 52,4 \% опитаних першокурсників назвали напругу і втому від занять. Майже половина студентів, які брали участь в анкетуванні, визначили дуже великий обсяг роботи, яку треба виконати самостійно. На підготовку до занять 68 \% студентів витрачають від 4 і більше годин. Найважчим у навчанні 60 \% опитуваних визнали опанування нових його форм, а 26 \% анкетованих першокурсників складно пристосовувалися до вимог викладачів. Також деякі студенти відмітили, що отримали недостатню підготовку в школі (19 \% анкетованих). Виявилось, що для деяких першокурсників складно раціонально організувати відпочинок і робочий час, налагодити режим дня і харчування (15 \%). «Навчання - моя основна турбота на сьогодні», - вважають 73,3 \% опитаних молодих людей.

Для визначення стану психологічної адаптації студентам було запропоновано обрати емоційні стани, які їх турбують у процесі навчання на сьогодні. Виявилось, що майже кожен другий 3 опитаних першокурсників мають такі проблеми, як підвищення тривожності, внутрішня напруга, порушення сну, невпевненість у своїх силах, порівняння себе з іншими. Результати анкетування за цим питанням свідчать, що психологічна адаптація не закінчена, ба більше, вона може бути ускладнена переходом до дистанційного навчання [4, 9, 17$]$.

Вважають, що багатьом студентам потрібна допомога батьків, викладачів, друзів, одногрупників. Отримані нами дані свідчать про те, що сьогоднішні першокурсники намагаються самостійно знаходити раціональні шляхи вирішення проблемних ситуацій (50,8 \% анкетованих). Такий же від- 
соток першокурсників у разі потреби звернулися би до одногрупників або до друзів. Привертає увагу той факт, що тільки 18,6 \% студентів готові консультуватися $з$ проблемних питань з батьками, хоча переважна більшість першокурсників під час дистанційного навчання проживає вдома, зі своїми родинами. В дослідженнях [10] встановлено, що студенти, які проживають із батьками, краще уникають стресу і скоріше пристосовуються до навчання. Роль батьків у формуванні успішної адаптації безперечна $[14,16]$, вона полягає не стільки в здійсненні постійного контролю за успішністю своєї дитини, її проживанням, хоча це дуже важливо, а й в допомозі своїй дитині створити стан психологічного комфорту, що, на нашу думку, є обов'язком батьків. Також, виходячи з результатів анкетування, актуальною проблемою постає питання щодо збільшення частки впливу на процеси адаптації студентів-першокурсників з боку викладачів, психологічної служби університету, які є професіоналами з цього питання.

Вважають, що одним із важливих факторів успішної адаптації є сприятливий мікроклімат у групі [1], що підтвердили і наші опитані. Першокурсники визнали, що в їх групах переважає доброзичливе ставлення один до одного (90,2 \% анкетованих), більшість студентів (93,4%) визнала свої відносини з одногрупниками товариськими або частково товариськими. Майже половина опитаних студентів, а саме 51,2 \%, вважає, що на результати навчання (як позитивно, так і негативно) можуть впливати взаємовідносини з одногрупниками, тому завжди намагаються підтримувати один одного, будувати теплі і дружні стосунки.

Наступний блок питань стосувався визначення стану задоволення студентів організацією дистанційного навчання в нашому університеті і рівнем адаптації до процесу отримання знань таким способом. У Запорізькому державному медичному університеті перехід на дистанційну форму навчання відбувся за допомогою програми Microsoft @ Teams, що використовується всіма учасниками навчального процесу. Всі заняття відбуваються в реальному часі, за розкладом навчального відділу, з використанням камер, мікрофонів, тобто $з$ повною візуалізацією. Окрім того, якщо є необхідність в особистому спілкуванні, наприклад викладача, куратора, деканату зі студентом, або, навпаки, коли у першокурсника виникає необхідність комунікації з іншими студентами або з педагогами, це завжди можливо зробити за допомогою відеозв’язку «один на один» або в груповому чаті, можливим є спілкування за допомогою миттєвих повідомлень.

Серед труднощів, які заважають у дистанційному навчанні, 92 \% опитаних студентів назвали «нестабільну роботу Інтернету». Іншими причинами, які, на думку першокурсників, ускладнюють роботу он-лайн, були складність зосередження уваги на практичних заняттях і лекціях, спокуса займатися іншими справами вдома, недостатність спілкування зі своїми одногрупниками. При цьому студенти відзначили, що організація навчального процесу в ЗДМУ їх дисциплінує, мотивує на найкращу роботу і на відповідальне ставлення до навчання. Проте тільки 43,2 \% учасників анкетування визнали, що вони беруть активну участь у спілкуванні он-лайн на заняттях, інші студенти вказали, що відповідають не за особистим бажанням, а на вимогу викладача.

В умовах дистанційного навчання виникла потреба в удосконаленні електронних ресурсів кафедр тому, що саме з них студенти отримують переважну більшість навчально-методичних матеріалів. Лише 5,1 \% з опитаних студентів повідомили, що зовсім не користуються електронними ресурсами кафедр, а інші студенти визнали, що активно застосовують для підготовки до занять презентації, тести, які розташовані на порталах кафедр, і вважають такий спосіб розміщення інформації якісним, доступним.

Щодо організації навчального процесу в університеті, високий рівень якої відмітили студенти, потрібно зазначити, що для його досягнення професорсько-викладацький склад й адміністрація університету також пройшли потужну адаптацію. B умовах навчання на онлайн-платформах перед керівництвами ЗВО постало завдання забезпечення всіх співробітників технікою для проведення занять (комп’ютери, камери, мікрофони тощо), вибору і закупівлі найкращого програмного забезпечення. Виникла потреба суттєвих змін до розкладу занять з урахуванням дистанційної форми навчання. Першочерговими завданнями, які треба було виконати в умовах переходу на онлайн-навчання, стали освоєння нового програмного забезпечення, створення сучасних за формою і контентом лекцій, практичних занять, які би максимально сприяли розвитку знань і навичок студентів. Загалом, проблема адаптації для більшості викладачів у нашому закладі пройшла вдало.

Кафедрами університету був набутий безцінний досвід, який використовується в сьогодніш- 
ніх умовах змішаної форми навчання. На початку 2021-2022 навчального року заняття проводилися в аудиторіях. Коли виникла потреба переходу на дистанційне навчання, то всі учасники процесу вже були готові до цього. Одним із важливих моментів його здійснення став формат спілкування за умови повної візуалізації, який сприяє не тільки якісному навчанню, а ще й психологічній адаптації, що підтверджено дослідженнями [6, 17]. Автори вивчали можливості надання психологічної підтримки студентам, які потрапили у вимушену соціальну ізоляцію у зв'язку з поширенням коронавірусної інфекції і переходом на дистанційне навчання. Було встановлено, що велика кількість студентів відчула посилення тривожності й самотності. У зв’язку з цим, авторами запропонована чітка система контакту зі студентами, яка полягає в обов'язковій візуалізації спілкування з одногрупниками, тобто з людьми, які опинилися в таких же умовах, з викладачами, до яких у разі потреби можна звернутися за допомогою. Важливим фактором для підтримки відчуття благополуччя молодих людей є перспектива зустрічі з одногрупниками, тобто чітко визначений час зустрічі, що стимулює студента до правильної організації робочого й особистого часу.

Враховуючи вищевикладене, можна зробити висновок, що при змішаній формі навчання в умовах карантинних обмежень особливостями загальної адаптації студентів першого курсу медичного факультету є певні зміни у проявах кожної з її складових: соціальні і біологічні аспекти набувають більш легкої форми, ніж при звичайній аудиторній формі організації навчального процесу, дидактичні зостаються досить важкими для студентів, а психологічні і професійні ускладнюються. Тому існує потреба у подальшому дослідженні проблемних складових адаптаційного процесу з метою розробки засобів, які би сприяли полегшенню його перебігу.

Висновки та перспективи подальших досліджень. 1. Загальна адаптація студентів першого курсу медичного факультету до навчання при зміша-

\section{Список літератури}

1. Ваценко А. В. Сучасний погляд на проблему дидактичної адаптації / А. В. Ваценко, Н. А. Улановська-Циба, Н. О. Передерій // Editorial board. - 2020. - Р. 279. Режим доступу : http://elib.umsa.edu.ua.

2. Проблема адаптації студентів-медиків першого курсу до навчального процесу / А. Очеретнюк, Д. Лисенко, О. Паламарчук [та ін.] // Вісник Вінницького ній формі дистанційного навчання в умовах карантинних обмежень має особливості в усіх її аспектах.

2. Дистанційне навчання полегшує перебіг соціальної і біологічної складових адаптації, показником цього може бути збільшенні якісної успішності студентів, яке спостерігається в умовах повної візуалізації навчального процесу.

3. В умовах змішаної форми дистанційного навчання дидактичні аспекти адаптації зостаються традиційно досить важкими для першокурсників, а психологічні і професійні - ускладнюються, що потребує особливої уваги з боку організаторів навчального процесу.

4. Важливим завданням в умовах дистанційного навчання стає посилення психологічної підтримки студентів.

5. Дослідження особливостей загальної адаптації студентів і різних її аспектів при змішаній формі навчання має враховувати специфіку медичної освіти й сприяти розробці організаційних та методичних засобів, які би дозволили забезпечити високу якість освітнього процесу.

Перспективи подальших досліджень стосуються всіх аспектів загальної адаптації студентів до навчання в медичному університеті. Навіть полегшений перебіг соціальної та біологічної складових в умовах змішаної форми дистанційного навчання потребує вивчення, а саме, неясно, якою мірою вони сформувались, і як це буде впливати при переході у звичайний аудиторний формат навчання. Важливим є визначення причин психологічного дискомфорту студентів при змішаній формі дистанційного навчання - чи є він наслідком обмеженого «живого» спілкування з викладачами й однокурсниками, чи зв'язаний із загальною ситуацією у світі, викликаною пандемією, або зумовлений психологічними особливостями студентів тощо. Також потребують дослідження дидактичний та професійний аспекти загальної адаптації з метою виявлення факторів, які можуть поліпшити їх перебіг, і розробки відповідних організаційних та методичних засобів.

національного медичного університету. - 2018. T. 22, № 3. - C. 543-547. DOI https://doi.org/https://doi. org/10.31393/reports-vnmedical-2018-22(3)-31.

3. Успеваемость студентов первокурсников как показатель адаптации к обучению в медицинском вузе / О. В. Кузнецова, Е. А. Нефедова, В. Ф. Шаторная [и др.] // Вісник проблем біології і медицини. - 2016. - 
Вип. 4, т. 1 (133). - С. 218-221. - Режим доступу : http:// repo.dma.dp.ua/id/eprint/1881.

4. Academic coaching of medical students during the COVID-19 pandemic / I. C. Lee, H. Koh, S. H. Lai [et al.] // Medical education. - 2020. - Vol. 54, No. 12. - P. 1184 1185. DOI https://doi.org/10.1111/medu.14272.

5. Adjusting to university: Perceptions of first-year health professions studentsof first-year health professions students / B. S. Malau-Aduli, M. D. Adu, F. Alele [et al.] // PLoS One. 2021. - Vol. 16 (5). DOI 10.1371/journal.pone.0251634.

6. A wellness program for first year medical students / A. McGrady, J. Brennan, D. Lynch [et al.] // Applied psychophysiology and biofeedback. - 2012. - Vol. 37 (4). P. 253-260. DOI 10.1007/s10484-012-9198-x.

7. Clinciu A. I. Adaptation and Stress for the First Year University Student / A. I. Clinciu // Procedia-Social and Behavioral Sciences. - 2013. - Vol. 78. - P. 718-722. DOI https://doi.org/10.1016/j.sbspro.2013.04.382.

8. Eva K. W. Really Good Stuff for educational transition during a pandemic / K. W. Eva, M. B. Anderson // Medical Education Adaptations. - 2020. - Vol. 54, No. 6. - P. 494. DOI https://doi.org/10.1111/medu.14172.

9. Hodgson J. C. Medical education adaptations during a pandemic: Transitioning to virtual student support / J. C. Hodgson, P. Hagan // Medical Education Adaptations. - 2020. - Vol. 54, No. 7. - P. 662-663. DOI https:/ doi.org/10.1111/medu.14177.

10. Inverse Correlation between Stress and Adaptive Opining in Medical Students / Z. Rasheed, A. Shariq [et al.] // Open Access Macedonian Journal of Medical Sciences. - 2020. - Vol. 8(E). - P. 623-629. DOI 10.3889/ oamjms.2020.5115.

11. Keegan D. A. Helping medical educators worldwide to pivot curricula online: pivotmeded.com / D. A. Keegan,

\section{References}

1. Vatsenko, A.V., Ulanovska-Tsyba, N.A., \& Perederii, N.O. (2020). Suchasnyi pohliad na problemu dydaktychnoi adaptatsii [Modern view on the problem of didactic adaptation]. Editorial Board, 279. Retrieved from: http:// elib.umsa.edu.ua [in Ukrainian].

2. Ocheretnyuk, A., Lysenko, D., \& Palamarchuk, O. (2018). Problema adaptatsiyi studentiv-medykiv pershoho kursu do navchalnoho protsesu [The problem of adaptation of first-year medical students to the educational process]. Visnyk Vinnytskoho natsionalnoho medychnoho universytetuBulletin of Vinnytsia National Medical University, 22(3), 543-547. DOI https://doi.org/https://doi.org/10.31393/reports-vnmedical-2018-22(3)-31 [in Ukrainian].

3. Kuznecova, O.V., Nefedova, E.A., Shatornaya, V.F., \& Demidenko, Yu.V. (2016). Uspevaemost studentov pervokursnikov kak pokazatel adaptacii k obucheniyu v medicinskom vuze [First-year students' progress as an indicator of adaptation to training in a medical university]. Visnyk prob-
M. Chan, T. M. Chan // Medical Education Adaptations. 2020. - Vol. 54, No. 6. - P. 766-767. DOI https://doi. org/10.1111/medu.14220.

12. Levchenko K. V. Features of the 1st year students' adaptation to the study process at the medical universities in Ukraine / K. V. Levchenko // Zbiór artykułów naukowych z Konferencji Miedzynarodowej Naukowo-Praktycznej (online) «Science, research, development. Pedagogy. \#2». 2018. - S. 131-134. - Access mode : http://repo.dma.dp.ua/ $\mathrm{id} / \mathrm{eprint} / 2703$.

13. MedicalStudents' Perception about Online Teaching Methods during COVID-19 Pandemic / A. Kui, M. Negucioiu, A. Berar [et al.] // Journal of Evolution of Medical and Dental Sciences. - 2020. - Vol. 9, No. 48. P. 3638-3642. DOI 10.14260/jemds/2020/799.

14. Parent and Family Engagement in Higher Education: AEHE / J. M. Kiyama, C. E. Harper, D. Ramos [et al.] // ASHE Higher Education Report. - 2015. - Vol. 41, No. 6. P. 1-94. - Access mode : https://scholar.google.com.

15. Salgar S. T. Stress in First Year Medical Students / S. T. Salgar // International Journal of Biomedical and Advance Research. - 2014. - Vol. 5, No. 1. - P. 5-7. DOI https://doi.org/10.7439/ijbar.v5i1.580.

16. The Effects of Parental and Peer Attachment on University Adjustment among First-Year Undergraduate Students / G. Su-wan, C. Min-Shern, C. Keng-Leong, W. Li-Xin // Advances in Social Science, Education and Humanities Research (Proceedings of the 2nd International Conference on Intervention and Applied Psychology). 2019. - Vol. 229. - P. 682-691. DOI https://doi.org/10.2991/ iciap-18.2019.58.

17. Wilcha R. Effectiveness of Virtual Medical Teaching During the COVID-19 Crisis: Systematic Review / R. Wilcha // JMIR Medical Education. - 2020. - Vol. 6, No. 2. - P. 13-25. DOI 10.2196/20963.

lem biolohii i medytsyny - Bulletin of Problems of Biology and Medicine, 4, 1(133), 218-221. Retrieved from: http:// repo.dma.dp.ua/id/eprint/1881 [in Russian].

4. Lee, I.C., Koh, H., \& Lai, S.H. (2020). Academic coaching of medical students during the COVID-19 pandemic. Medical Education, 54(12), 1184-1185. DOI https://doi. org/10.1111/medu.14272.

5. Malau-Aduli, B.S., Adu, M.D., Alele, F., Jones, K., Drovandi, A., Mylrea, M., ... Jennings, E. (2021). Adjusting to university: Perceptions of first-year health professions students of first-year health professions students. PLoS One, 16(5). DOI 10.1371/journal.pone.0251634.

6. McGrady, A., Brennan, J., Lynch, D., \& Whearty, K. (2012). A wellness program for first year medical students. Applied Psychophysiology and Biofeedback, 37(4), 253-260. DOI 10.1007/s10484-012-9198-X.

7. Clinciu, A.I. (2013). Adaptation and Stress for the First Year University Student. Procedia-Social and Behavioral 
Sciences, 78, 718-722. DOI https://doi.org/10.1016/j.sbspro.2013.04.382.

8. Eva, K.W., \& Anderson, M.B. (2020). Really Good Stuff for educational transition during a pandemic. Medical Education Adaptations, 54(6), 494. DOI https://doi. org/10.1111/medu.14172.

9. Hodgson, J.C., \& Hagan, P. (2020). Medical education adaptations during a pandemic: Transitioning to virtual student support. Medical Education Adaptations, 54(7), 662663. DOI https://doi.org/10.1111/medu.14177.

10. Rasheed, Z., Shariq, A., Alsalhi, A., Almesned, S., Alhussain, S., Alshammari, A., ... Abdulmonem, W. (2020). Inverse Correlation between Stress and Adaptive Opining in Medical Students. Open Access Macedonian Journal of Medical Sciences, 8(E), 623-629. DOI 10.3889/oamjms.2020.5115.

11. Keegan, D.A., Chan, M., \& Chan, T.M. (2020). Helping medical educators worldwide to pivot curricula online: pivotmeded.com. Medical Education Adaptations, 54(6), 766-767. DOI https://doi.org/10.1111/medu.14220.

12. Levchenko, K.V. (2018). Features of the 1st year student's adaptation to the study process at the medical universities in Ukraine. Zbiór artykułów naukowych z Konferencji Miedzynarodowej Naukowo-Praktycznej (on-line) "Science, research, development. Pedagogy. \#2”. (pp. 131-134). Retrieved from: http://repo.dma.dp.ua/id/eprint/2703.
13. Kui, A., Negucioiu, M., Berar, A., Fluerasu, M., Iacob, S., Manziuc, M., ... Buduru, S. (2020). Medical Students' Perception about Online Teaching Methods during COVID-19 Pandemic. Journal of Evolution of Medical and Dental Sciences, 9(48), 3638-3642. DOI 10.14260/ jemds/2020/799.

14. Kiyama, J.M., Harper, C.E., \& Riester, K.A. (2015). Parent and Family Engagement in Higher Education. ASHE Higher Education Report, 41(6), 1-94. Retrieved from: https://scholar.google.com.

15. Salgar, S.T. (2014). Stress in First Year Medical Students. International Journal of Biomedical and Advance Research, 5(1), 5-7. DOI https://doi.org/10.7439/ijbar. v5i1.580.

16. Su-wan, G., Min-Shern, G., \& Li-Xin, W. (2019). The Effects of Parental and Peer Attachment on University Adjustment among First-Year Undergraduate Students. Advances in Social Science, Education and Humanities Research (Proceedings of the 2nd International Conference on Intervention and Applied Psychology), 229, 682-691. DOI https:// doi.org/10.2991/iciap-18.2019.58.

17. Wilcha, R. (2020). Effectiveness of Virtual Medical Teaching During the COVID-19 Crisis: Systematic Review. JMIR Medical Education, 6(2), 13-25. DOI 10.2196/20963. 